\title{
GYRFALCON FALCO RUSTICOLUS POST-GLACIAL COLONIZATION AND EXTREME LONG-TERM USE OF NEST SITES IN GREENLAND
}

\author{
Kurt K. Burnham, ${ }^{1,2,+}$, William A. Burnham, ${ }^{2, \wedge}$, and IAn NeWtON ${ }^{3}$ \\ ${ }^{1}$ Edward Grey Institute, Department of Zoology, University of Oxford, \\ South Parks Road, Oxford, OX1 3PS, UK. \\ E-mail: kburnham@higharctic.org \\ ${ }^{\dagger}$ Present address: High Arctic Institute, 603 10th Avenue, Orion, IL 61273, USA \\ ${ }^{2}$ The Peregrine Fund, 5668 West Flying Hawk Lane, Boise, ID 83709, USA \\ ${ }^{3}$ Centre for Ecology \& Hydrology, Maclean Building, Benson Lane, Crowmarsh, Gifford, \\ Wallingford, Oxon OX10 8BB, UK
}

${ }^{\wedge}$ Deceased

\begin{abstract}
Gyrfalcons (Falco rusticolus) use the same nest-sites over long periods of time, and in the cold dry climate of Greenland, guano and other nest debris decay slowly. Nineteen guano samples and three feathers were collected from 13 Gyrfalcon nests with stratified faecal accumulation in central-west and northwest Greenland. Samples were ${ }^{14} \mathrm{C}$ dated, with the oldest guano sample dating to $c$.2740-2360 calendar years (cal yr) before present (BP) and three others were likely $>1000$ cal yr BP. Feather samples ranged from 670 to $60 \mathrm{cal} \mathrm{yr}$ BP. Although the estimated age of material was correlated with sample depth, both sample depth and guano thickness gave a much less reliable prediction of sample age than use of radiocarbon dating on which the margin of error was less. Older samples were obtained from sites farther from the current Greenland Ice Sheet and at higher elevations, while younger samples were closer to the current ice sheet and at lower elevations. Values for $\delta^{13} \mathrm{C}$ showed that Gyrfalcons nesting further from the Greenland Ice Sheet had a more marine diet while those nesting closer to the ice sheet (= further inland) fed on a more terrestrial diet. The duration of nest site use by Gyrfalcons is a probable indicator of both the time at which colonization occurred and of the palaeoenvironmental conditions and patterns of glacial retreat. Nowhere before has such extreme long-term to present use of raptor nest sites been documented. Reproduced with permission of the authors from Ibis (2009) 151:514-522.
\end{abstract}

Burnham, K. K., W. A. Burnham, AND I. Newton. 2011. Gyrfalcon Falco rusticolus post-glacial colonization and extreme long-term use of nest sites in Greenland. Reproduced, pages 81-92 in R. T. Watson, T. J. Cade, M. Fuller, G. Hunt, and E. Potapov (Eds.). Gyrfalcons and Ptarmigan in a Changing World, Volume II. The Peregrine Fund, Boise, Idaho, USA. http://dx.doi.org/ 10.4080/gpcw.2011.0123

Key words: Carbon dating, guano, palaeoenvironmental conditions, $\delta^{13} \mathrm{C}$. 
IT IS WELL KNOWN that raptors may re-use nest sites for generations and some possibly for centuries (Newton 1979). Hickey (1942) referred to these nest sites as "ecological magnets." These locations are evidently so desirable that they are re-used again and again, even if the birds have no former familiarity with the location. For example, Peregrine Falcons (Falco peregrinus) disappeared from large areas of North America and Europe during the 1960s as a result of organochlorine pesticide use. Many years later, following the restriction in the use of these chemicals, released or recolonizing Peregrines usually reoccupied former territories first, frequently re-using the same nest ledges as their predecessors (Newton 1979, Ratcliffe 1993, Oakleaf 2003).

Gyrfalcons (Falco rusticolus) and Peregrine Falcons both breed in the Arctic. Falcons do not build nests, but lay eggs in bowl-shaped depressions they scrape into existing substrates, including old nests made by other birds. Arctic Peregrine Falcons typically use open ledges on cliffs for nesting with little protection from the weather (Cade 1960). Gyrfalcons usually nest on cliff ledges overhung by rock, in potholes, or in sheltered stick-nests built by Northern Ravens Corvus corax (Cade 1960, Burnham and Mattox 1984). These nesting situations provide protection from falling rock and the extreme weather conditions often found during the early part of the Gyrfalcon breeding season. While stick nests are frequently damaged beyond re-use in a single season, some ledges and potholes are used long-term by Gyrfalcons (Burnham and Mattox 1984). Gyrfalcons and Northern Ravens do not seem to alternate the use of the same nest site from year to year in Greenland. At reused sites, faecal accumulation frequently occurs where Gyrfalcons roost and nest. Deposited over periods of years, the stratified accumulation of guano can become greater than $1.5 \mathrm{~m}$ thick in locations protected from erosion and where dry and cold environmental conditions enhance preservation (Figure 1).

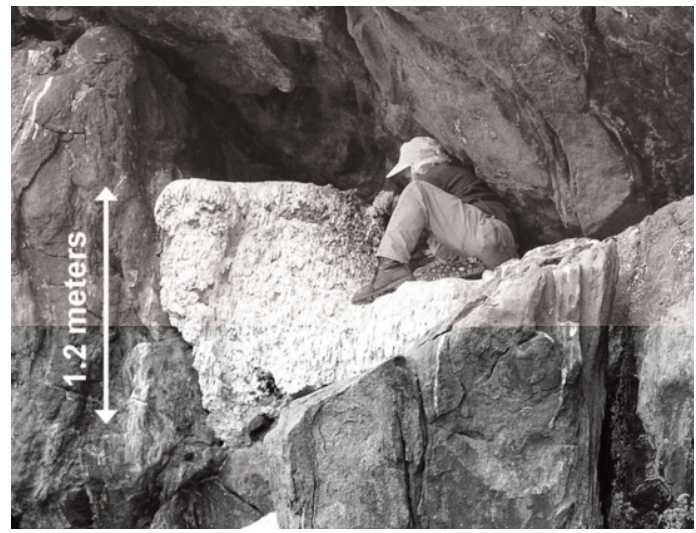

Figure 1. Gyrfalcon nest site 123 being sampled for radiocarbon dating in Kangerlussuaq, central-west Greenland, with a ${ }^{14} \mathrm{C}$ age of 1160 to 920 cal yr BP.

There are many such nest sites throughout icefree areas of Greenland.

The Greenland Ice Sheet covers $82 \%$ of the land mass of Greenland (Ohmura et al. 1999), and ice-free land occurs only along the periphery of the island. Nest-site availability for falcons may be affected by climate-induced glacial retreat and advance covering and exposing cliffs. Long-term use of nest-sites by Gyrfalcons is a potential indicator for palaeoenvironments and of stable glacial conditions. As the ice sheet retreated, areas at higher elevations, having a thinner layer of ice and snow, were exposed first. Land at lower elevations, particularly valley bottoms, had the thickest covering of ice and were exposed last (Fristrup 1966). We therefore hypothesized that guano in Gyrfalcon nests at lower elevations and closer to the current ice sheet would have accumulated over shorter periods than that at nests at higher elevations and further from the current Greenland Ice Sheet. To investigate this question we sampled and radiocarbon dated guano from Gyrfalcon nestsites in two areas, in Kangerlussuaq, centralwest $\left(66.50-67.00^{\circ} \mathrm{N}\right)$, and Thule, northwest $\left(76.25-77.17^{\circ} \mathrm{N}\right)$, Greenland. These study areas were separated by about $9^{\circ}$ latitude and $1100 \mathrm{~km}$. 


\section{Study AREAS}

The Kangerlussuaq study area is located at the head of a 175-km-long fjord and about $25 \mathrm{~km}$ from the current ice sheet margin. The Low Arctic tundra landscape in this area was sculpted by glaciation, with rolling hills and valleys, moraines and lakes, dissected by several meltwater rivers, and dominated mainly by shrubs up to $2 \mathrm{~m}$ in height. Primary prey species for Gyrfalcons in Kangerlussuaq include both Rock Ptarmigan (Lagopus mutus) and Arctic Hare (Lepus arcticus), with lesser quantities of passerines and waterfowl consumed (Booms and Fuller 2003). It is one of the largest deglaciated land areas in Greenland and, because of extensive past research, provides one of the most complete records of Greenland's glacial history (Ten Brink and Weidick 1974, Eisner et al. 1995). From projected rates of deglaciation (see below), we can estimate that some Gyrfalcon nest-sites may have been uncovered c. 6500-6000 years before present (yr BP).

The Thule study area is centered around Pituffik/Thule Air Base and the current ice sheet margin lies up to $26 \mathrm{~km}$ inland from the sea, but it reaches the sea at several locations. The environment is High Arctic with an appearance of recent deglaciation, and sparsely vegetated prostrate growing herbs and shrubs. In this area, Gyrfalcons fed primarily on Little Auks (Alle alle), Rock Ptarmigan and Arctic Hares, with seabirds, waterfowl, and passerines taken in smaller numbers (Burnham 2008). Information on glaciation in Thule is more limited than for Kangerlussuaq, and glacial history is predicted more from inference of past climates than from moraine locations and measurement (Davies et al. 1963, Fredskild 1985, Kelly et al. 1999). Deglaciation sufficient to allow for consistent use of existing Gyrfalcon nest sites may not have occurred until $1350 \mathrm{yr}$ BP or more recently (see below).

\section{MeTHODS}

Gyrfalcon nest-sites are distributed widely and irregularly throughout the two study areas and Greenland as a whole. All sites are on cliffs and usually inaccessible without technical rock climbing equipment. The amount of faecal material build-up at sites varies greatly, as does the structure and size of the nest. The rock substrate upon which falcon guano accumulates is usually irregular, sloping, and seldom flat. Particularly on large ledges, the actual nest scrape is not always in the same location each year, nor is the associated faecal deposition resulting from breeding. Also, the rates of erosion are probably not constant across the nest, as some locations in the nest are more protected from weather than are others. Therefore, the guano is not of constant depth throughout the site, and it is difficult to know where the thickest and/or oldest deposits may lie. At nest-sites where deposits seemed of more-or-less uniform thickness throughout, a single sample was collected where guano came in contact with the rock, while at other sites more than one sample was collected in an attempt to obtain the oldest guano. Bulk sample materials were collected from several centimeters of stratified guano, probably representing accumulation over decades or longer. Notes were made of sample depth $(\mathrm{cm})$, cliff height $(\mathrm{m})$, and nest ledge elevation (meters above sea level, m asl). All nests sampled had been occupied by Gyrfalcons within the past 25 years (Table 1 ).

When collecting samples, layers of faecal build-up were excavated carefully to prevent damage of the site for future use by Gyrfalcons. At nest-sites with only a few centimeters of faecal build-up, we dug vertically down into the guano, extracted samples at its base, and then refilled the hole to minimize damage to the nest site. At sites with substantial build-up, samples were taken from the side by using a 
Table 1. Results of the $14 \mathrm{C}$ measurements on guano material and feathers from Gyrfalcon nest sites in Kangerlussuaq, central-west, and Thule, northwest Greenland, collected from 2002 to 2004. Samples from the same nest site are designated by the use of $A, B, C$, or D following the number.

\begin{tabular}{|c|c|c|c|c|c|c|c|c|c|}
\hline $\begin{array}{l}\text { Nest- } \\
\text { site }\end{array}$ & $\begin{array}{c}\text { Beta } \\
\text { analytic } \\
\text { sample \# }\end{array}$ & $\begin{array}{l}\text { Sample } \\
\text { depth } \\
(\mathrm{cm})\end{array}$ & $\begin{array}{l}\text { Cliff } \\
\text { height } \\
(\mathrm{m})\end{array}$ & $\begin{array}{l}\text { Nest } \\
\text { elevation } \\
\text { (m asl) }\end{array}$ & $\begin{array}{l}\text { Distance } \\
\text { from ice } \\
\text { margin } \\
(\mathrm{km})\end{array}$ & $\begin{array}{c}\delta^{13} \mathrm{C} \\
(\% \circ) \\
(\mathrm{PDB})\end{array}$ & $\begin{array}{l}\text { Last } \\
\text { used }\end{array}$ & $\begin{array}{l}\text { Conventional } \\
{ }^{14} \mathrm{C} \text { age } \\
(\mathrm{yr} \mathrm{BP} \pm 1 \sigma)\end{array}$ & $\begin{array}{c}\text { Calibrated } \\
\text { age range } \\
(\text { cal yr BP } \pm 2 \sigma)\end{array}$ \\
\hline \multicolumn{10}{|c|}{ Kangerlussuaq, central-west Greenland } \\
\hline 019 & 195586 & $20-25$ & 15 & 355 & 9 & -22.7 & 1992 & $790 \pm 60$ & $790-650$ \\
\hline 053A & 191125 & 30-35 & 15 & 304 & 11 & -22.4 & 1991 & $1290 \pm 50$ & $1300-1080$ \\
\hline 053B & 191126 & $15-20$ & 15 & 304 & 11 & -22.4 & 1991 & $1090 \pm 80$ & $1180-900,850-810$ \\
\hline 053C & 191295 & 15 & 15 & 304 & 11 & -22.5 & 1991 & $320 \pm 30$ & 470-300 \\
\hline 068A & 191127 & $15-20$ & 152 & 55 & 14 & -22.9 & 2000 & $570 \pm 50$ & $650-520$ \\
\hline 068B & 195576 & $10-15$ & 152 & 55 & 14 & -20.7 & 2000 & $240 \pm 60$ & $\begin{array}{c}450-260,220-140 \\
30-0\end{array}$ \\
\hline 082 & 195577 & $25-30$ & 76 & 441 & 5 & -23.2 & 1999 & $830 \pm 70$ & $920-660$ \\
\hline 087A & 168839 & $30-35$ & 46 & 365 & 54 & -21.9 & 2002 & $2480 \pm 40$ & 2740-2360 \\
\hline 087B & 168840 & $25-30$ & 46 & 365 & 54 & -20.9 & 2002 & $350 \pm 40$ & $500-300$ \\
\hline 087C & 168838 & $0-3$ & 46 & 365 & 54 & -24.2 & 2002 & $105.09 \pm 0.66 \mathrm{pMC}^{\mathrm{b}}$ & $\begin{array}{c}\text { outside } \\
\text { calibration range }\end{array}$ \\
\hline 087D & 168837 & 15 & 46 & 365 & 54 & -21.3 & 2002 & $170 \pm 40$ & $300-60,40-0$ \\
\hline 123 & 195578 & 20-25 & 46 & 258 & 62 & -21.1 & $\sim 1985$ & $1090 \pm 60$ & 1160-920 \\
\hline 163 & 195587 & $100-110$ & 152 & 395 & 72 & -20.8 & 2003 & $960 \pm 60$ & $970-740$ \\
\hline 170 & 195579 & $15-20$ & 24 & 103 & 28 & -21.3 & 2004 & $690 \pm 60$ & $710-550$ \\
\hline $201 \mathrm{~A}$ & 195580 & $35-40$ & 23 & 200 & 78 & -17.8 & 2000 & $1430 \pm 70$ & $\begin{array}{l}1480-1470 \\
1430-1250\end{array}$ \\
\hline 201B & 195581 & $10-15$ & 23 & 200 & 78 & -21.3 & 2000 & $820 \pm 60$ & $910-660$ \\
\hline \multicolumn{10}{|c|}{ Thule, northwest Greenland } \\
\hline $500 A$ & 195583 & $5-8$ & 46 & 152 & 14 & -23.3 & 2003 & $113.34 \pm 0.71 \mathrm{pMC}^{\mathrm{b}}$ & $\begin{array}{c}\text { outside } \\
\text { calibration range }^{b}\end{array}$ \\
\hline $500 \mathrm{~B}$ & 195582 & $3-6$ & 46 & 152 & 14 & -21.2 & 2003 & $122.08 \pm 0.73 \mathrm{pMC}^{\mathrm{b}}$ & $\begin{array}{c}\text { outside } \\
\text { calibration range }^{b}\end{array}$ \\
\hline 501 & 195584 & $2-4$ & 117 & 122 & 2 & -23.2 & 2004 & $115.29 \pm 0.66 \mathrm{pMC}^{\mathrm{b}}$ & $\begin{array}{c}\text { outside } \\
\text { calibration range }\end{array}$ \\
\hline 502 & 195585 & $15-20$ & 23 & 152 & 9 & -20.2 & 2004 & $640 \pm 50$ & $670-540$ \\
\hline $503 A$ & 191124 & $20-25$ & 76 & 304 & 17 & -19.1 & 2004 & $650 \pm 70$ & $690-530$ \\
\hline $503 \mathrm{~B}^{\mathrm{a}}$ & 191348 & 20 & 76 & 304 & 17 & -19.5 & 2004 & $650 \pm 40$ & $670-550$ \\
\hline
\end{tabular}

aGyrfalcon feather samples.

${ }^{b}$ pMC (percent Modern Carbon) analyzed material was post-1950 and had more ${ }^{14} \mathrm{C}$ than did the AD 1950 reference standard due to atomic bomb testing and subsequent fall-out, 50 years used as conventional ${ }^{14} \mathrm{C}$ age while

Calibrated Age Range is outside calibration range. 
masonry hammer and a small trowel to excavate horizontally until rock was reached. The amount of bulk material collected from the stratified samples varied, but in all cases was sufficient for dating using standardized radiocarbon procedures. Within the nest sites, feathers (from probable prey and/or Gyrfalcons) and bones (prey) were found during excavation. Three feathers that were easily identifiable as from Gyrfalcons were also radiocarbon dated.

Radiocarbon dating was carried out by Beta Analytic Inc, Miami, Florida, USA, using either the conventional radiometric technique (samples $>30 \mathrm{~g}$ ) or accelerator mass spectrometry (AMS) (samples < $30 \mathrm{~g}$ ). Guano samples were pre-treated using an "acid wash", while an "acid/alkali/acid" wash was used for feather samples. For the conventional radiometric technique, materials were analyzed by synthesizing carbon to benzene $(92 \% \mathrm{C})$ and then measuring for ${ }^{14} \mathrm{C}$ in a scintillation spectrometer from which the radiocarbon age was calculated (Beta Analytic). AMS results were obtained by the reduction of sample carbon to graphite $(100 \% \mathrm{C})$ along with standards and backgrounds (Beta Analytic). Graphite was then sent for ${ }^{14} \mathrm{C}$ measurement in an accelerator-mass-spectrometer to a research facility collaborating with Beta Analytic. The measured radiocarbon ages were returned to Beta Analytic where verification, isotopic fractionation correction using $\delta^{13} \mathrm{C}$, and calendar calibration took place (Beta Analytic). Calibrated results provide both a maximum and minimum age for each sample in calendar years (cal yr) before present (BP), with a $95 \%$ confidence that the actual age falls within this range. Calibrations were made using calibration data published in Stuiver et al. (1998) using cubic spline fit mathematics, as described by Talma and Vogel (1993).

From 2002 to 2004, 19 bulk guano samples and three feathers were collected from $13 \mathrm{Gyr}$ falcon nest sites. Five guano samples and one feather were from four nests in Thule, and 14 guano samples and two feathers were from nine nests in Kangerlussuaq. To test for relationships between age of guano samples and nest variables (using JMP IN, vs. 4, SAS Institute Inc.), we analyzed the distribution of the variables and relationships using Spearman Correlation Analysis, as was most appropriate based on the non-normal distribution of the data. Conventional ${ }^{14} \mathrm{C}$ age was used as the maximum age for each sample.

\section{Results}

The oldest guano sample was from nest site 087 in Kangerlussuaq and was dated 2740 to 2360 cal yr BP (Table 1). Three nests in Kangerlussuaq showed evidence of occupation $>1000$ cal yr BP, with the most recent nest being occupied from 650 to $520 \mathrm{cal} \mathrm{yr} \mathrm{BP.} \mathrm{In}$ Thule, the oldest nest was between 690 and $530 \mathrm{cal}$ yr BP with two nests indicating use only within the past 50 years (Table 1). Sites in Kangerlussuaq have been used approximately 1800 to 2000 years longer than those further north in Thule. Sites with multiple samples collected showed an increase in ${ }^{14} \mathrm{C}$ age with sample depth (Table 1). The three analyzed Gyrfalcon feathers were between 670 and 60 cal yr BP. Sample 087D had two possible calibrated age ranges, 300-60 and 40-0 cal yr BP, and the older range was most likely accurate based on other samples from the same nest and sample depth. While the bulk samples of guano represent a number of years of site use, the feathers were from a precise moment in time.

The maximum conventional ${ }^{14} \mathrm{C}$ age for each individual nest was significantly correlated with the current distance from the ice margin $\left(r_{s}=0.56, P<0.05, n=13\right.$, Figure 2$)$, nest elevation $\left(r_{S}=0.61, P<0.05, n=13\right.$, Figure 3$)$, and sample depth $\left(r_{s}=0.88, P<0.0001, n=\right.$ 13 , Figure 4$)$. While sample depth could be used as a predictor of ${ }^{14} \mathrm{C}$ age, the margin of error would be much greater than if using radio carbon dating directly (e.g., 087A and 163, Figure 4) 
In general, organisms from marine food chains or animals that feed on them have less negative $\delta^{13} \mathrm{C}$ values, while more negative $\delta^{13} \mathrm{C}$ values are typically associated with terrestrial ecosystems (Rounick and Winterbourn 1986, Angerbjörn et al. 1994). The $\delta^{13} \mathrm{C}$ values from the oldest guano sample from each nest varied slightly from a median of $-21.9 \% 0\left(n=9, \sigma^{2}=\right.$ 2.7) for Kangerlussuaq to $-21.5 \%$ o $\left(n=4, \sigma^{2}=\right.$ 4.5) for Thule, with no statistical difference between the two areas. A significant correlation exists between $\delta^{13} \mathrm{C}$ for the oldest guano sample from each nest and their current distance to the Greenland Ice Sheet $\left(r_{s}=0.63, P\right.$ $<0.05, n=13$ ), with less negative values being associated with nests further from the current ice sheet (Figure 5).

\section{Discussion}

Radiocarbon dating of Gyrfalcon nest material from Kangerlussuaq and Thule, Greenland, indicate much longer occupancy times than can be determined from historical records. Sites from Kangerlussuaq were colonized approximately 1800-2000 years earlier than those further north in Thule, probably an effect of earlier deglaciation and a more stable and warmer climate in the Kangerlussuaq area. These are some of the longest used raptor nest sites ever documented.

Similar studies of this type have been carried out on other Arctic and Antarctic species. These have included Snow Petrels (Pagodroma nivea) (Hiller et al. 1988), Thick-billed Murres (Uria lomvia) (Gaston and Donaldson 1995), and Adelie Penguins (Pygoscelis adeliae) (Emslie et al. 2007), for which radiocarbon age has been calculated using solidified stomach oil deposits, peat moss deposits, and bone and feather samples from molting sites, respectively, and minimum dates for the establishment or colonization of bird colonies have been given ( $34000 \mathrm{yr}$ BP, $1500-3800 \mathrm{yr} \mathrm{BP}$, and $>44000$ yr BP, respectively). In addition, archaeological studies have sometimes revealed long-term use of raptor nest-sites.

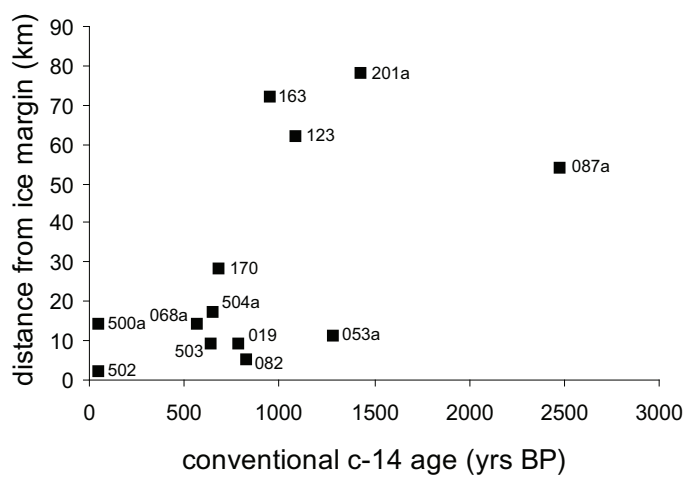

Figure 2. Relationship between maximum ${ }^{14} \mathrm{C}$ age and nest site distance from current ice margin $\left(r_{S}=0.56, P<0.05, n=13\right)$.

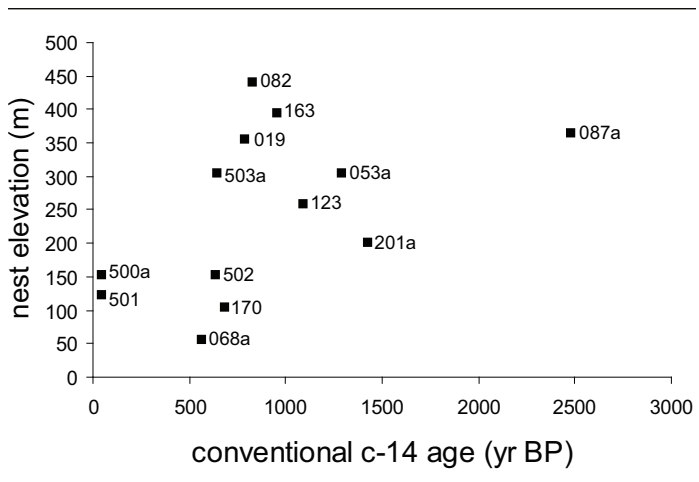

Figure 3. Relationship between maximum ${ }^{14} \mathrm{C}$ age and nest site elevation ( $m$ above sea level) $\left(r_{S}=0.61, P<0.05, n=13\right)$.

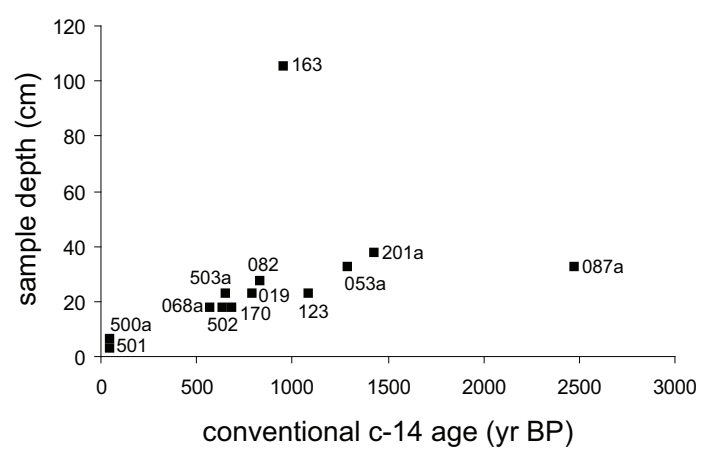

Figure 4. Relationship between maximum ${ }^{14} \mathrm{C}$ age and sample depth $\left(r_{S}=0.88, P<0.0001, n\right.$ $=13$ ). 


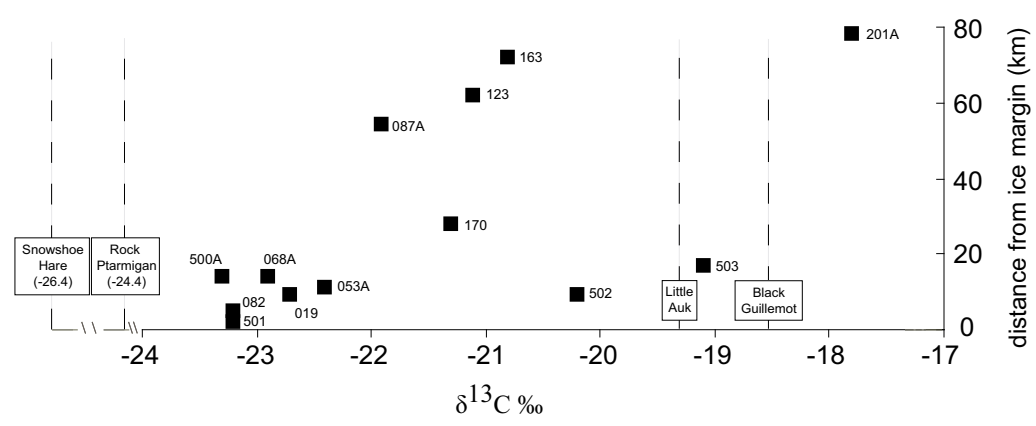

Figure 5. Relationship between $\delta^{13} \mathrm{C}$ and distance from current ice margin $\left(r_{S}=0.63, P<0.05, n=\right.$ 13). Frequent prey of Gyrfalcons shown with associated $\delta^{13} \mathrm{C}$ value. Snowshoe Hare (Lepus americanus) $\delta^{13} \mathrm{C}$ value was substituted for Arctic Hare as no values were found in the literature for Arctic Hare. $\delta^{13} \mathrm{C}$ values for Snowshoe Hare, Rock Ptarmigan, Little Auk, and Black Guillemot are from Roth et al. 2007, Ricca et al. 2007, Hobson et al. 2002, and Hobson et al. 2002, respectively.

For example, remains of Peregrine Falcons, probably adults and nestlings, were found during an archaeological investigation of prehistoric human occupation of a cave on Hunter Island, Tasmania (Bowdler 1984). Bones were found in layers $990 \pm 90$ to ca. $19000 \mathrm{yr}$ BP suggesting use by falcons during that time but not more recently.

There can be little doubt about the identity of the Gyrfalcon sites in Greenland. Only two falcon species breed there (Salomonsen 1950) and although Peregrines sometimes use former Gyrfalcon nest sites, these species typically select different nesting situations, as explained above. Cliff-nesting seabirds breed in different situations than do falcons. Gulls nest colonially and sites cannot be confused with falcon nests. Except for Iceland Gulls (Larus glaucoides) and Glaucous Gulls (L. hyperboreus), all other avian species breeding in the research areas construct nests containing sticks, grass, and feathers, and/or breed on the ground. Ravens are the only other cliff-nesting species that nest in similar locations to Gyrfalcons, but they construct stick-nests. There can be no doubt that the accumulation of guano at sites sampled resulted from long-term use by falcons, and in particular Gyrfalcons.

The feather samples could be easily identified to Gyrfalcons. Although interesting because of their condition and long-term preservation, they did not contribute to knowledge on duration of nest site use or palaeoenvironment beyond what could be inferred from guano samples. They did, however, provide confirmation of dates of past use.

Some nest-sites provided much older radiocarbon dated samples than others. Newton (1979) attributed the repeated occupancy of nest sites to "the superiority of particular places over local alternatives." This superiority could result from a nearby abundance of prey, a superior hunting platform, a location in appropriate spatial relationship to other territorial pairs, or a site offering good protection from mammalian predators or inclement weather (rain, snow, sun, and/or wind). Over time, the desirability of sites may change due to altered environmental conditions, including rock structure. This likelihood may be particularly true in areas of recent glacial activity and climate change. 
The Greenland Ice Sheet gradually retreated about $175 \mathrm{~km}$ in the Kangerlussuaq area because of world-wide climate warming since the end of the last glaciation ( 15000 yr BP), but with frequent re-expansions (Ten Brink and Weidick 1974, Funder 1989, Figure 6). A slow retreat of the ice sheet $(1 \mathrm{~km} / 100 \mathrm{yr})$ occurred from $c$. 15000 to $10000 \mathrm{yr}$ BP followed by an oscillatory but more rapid retreat (3 km/100 yr) of nearly $100 \mathrm{~km}$ from $c .9500$ to $6500 \mathrm{yr}$ BP (Ten Brink and Weidick 1974). By 6000 yr BP the ice sheet had reached its present position, although between 5- and 10$\mathrm{km}$ re-advances occurred from $c .4800$ to 4000 and from 2500 to $2000 \mathrm{yr}$ BP (Ten Brink and Weidick 1974, Figure 6). At that time the sea level was nearly equal to the present day. Eisner et al. (1995) reported that Kangerlussuaq experienced a "climatic optimum" from $c$. 4400 to $3400 \mathrm{yr}$ BP and that a climatically stable period is believed to have encompassed the period from 2000 to $1200 \mathrm{yr}$ BP (Figure 6). Based on lichenometry, the period from $c .700$ yr BP to the present was characterized by oscillatory advance and retreat of the inland ice within about a 3-km-wide zone (Ten Brink and Weidick 1974).

In Kangerlussuaq, nest-sites 019, 053, 068, 082 , and 170 were probably covered by ice during re-advances of glaciers from the Greenland Ice Sheet between c. 4800 and 4000 and from 2500 to $2000 \mathrm{yr}$ BP. All five nest-sites are in glacial valleys or river valleys and four of the five are on low cliffs. The fifth site (053) is near to the top edge of a deep valley. Furthermore, 068 and 170 are on small cliffs near low elevation rivers and even a $10 \mathrm{~m}$ rise in sea level could have affected use of these sites by Gyrfalcons. Nest sites 087, 123, 163, and 201 are less than $50 \mathrm{~km}$ from the ice edge and, based on the projected rate of ice-sheet retreat, these nest sites were ice-free by 6500 $6000 \mathrm{yr}$ BP. That does not preclude, however, the possibility of isolated snow banks and glaciers covering nest sites, particularly on small cliffs and at lower elevations, during periods of climatic cooling and glacial expansion. In addition, it was probably not until the "climatic optimum," from 4400 to $3400 \mathrm{yr}$ BP, that the necessary vegetation was established to support the prey-base utilized by Gyrfalcons in Kangerlussuaq.

Information from Thule is far less complete and more contentious than that from Kangerlussuaq. In Thule, Malaurie et al. (1972) used data from marine deposits of terraces to estimate that deglaciation began c. $8000 \mathrm{yr}$ BP, and Kelly et al. (1999) postulate that much of the area has been ice-free for at least 9000 years (Figure 6). From the period extending $8000-3000$ yr BP, the Thule area experienced a climatic optimum, with significant surface melting occurring (Reeh 1984, Figure 6). Archaeological evidence indicates unfavorable, cool conditions from 2500 to $1900 \mathrm{yr}$ BP followed by three centuries with a warmer climate (McGhee 1972, Figure 6). During the period c. 1350-900 yr BP, a moist and likely warm climate prevailed, with conditions cooling and vegetation changing to drier heath at the end of this period (Fredskild 1973, Figure 6). From c. $900 \mathrm{yr}$ BP to the $20^{\text {th }}$ century, considerable climatic variability existed, but evidence from ice cores and oxygen isotopic records from Camp Century show that generally cooler conditions probably persisted in the Thule area until c. 1900 AD (Johnsen et al. 1970). Meteorological records from Upernavik, Greenland $\left(72^{\circ} 50^{\prime} \mathrm{N}\right)$, show a $2^{\circ} \mathrm{C}$ mean annual temperature increase through the middle of the $20^{\text {th }}$ Century (Dowdeswell 1996).

In Thule, the existence of consistent long-term nest-site availability is more recent than in Kangerlussuaq. While some nest sites may have been ice-free as early as $c .9000-6000$ yr BP, they may have been later re-covered by re-advances of the ice sheet. Furthermore, despite some nest-sites being ice-free for extended periods of time, suitable environmental conditions for Gyrfalcons probably did not exist until between 1350 and 900 yr BP or later. Even now, because of cool mean sum- 


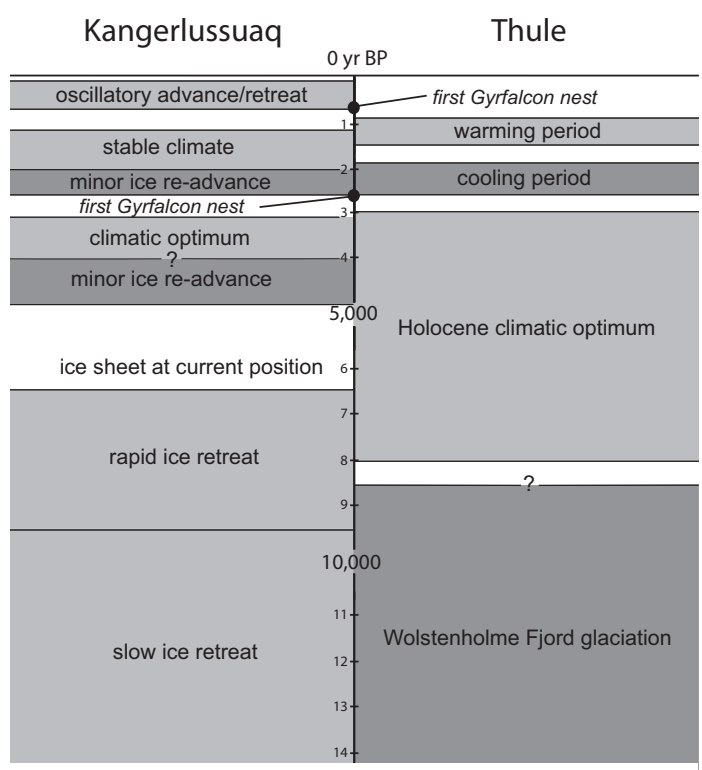

Figure 6. Glacial and climate history for the past $15000 \mathrm{yr}$ BP for the Kangerlussuaq and Thule study areas. For sources on dates used in the figure please see text.

mer temperatures, localized large snow banks and glaciers can develop in just a few years or decades and preclude the use of affected nest sites.

The significant correlation between $\delta^{13} \mathrm{C}$ values and distance to the current ice sheet is likely a reflection of diet, with Gyrfalcons breeding nearer the coast feeding on a mixed diet of marine and terrestrial prey items, and those breeding more inland having an almost completely terrestrial diet. Primary terrestrial prey items, such as Rock Ptarmigan and Arctic hare, have likely $\delta^{13} \mathrm{C}$ values in the range of -24 to $-27 \%$ o (Figure 5, Ricca et al. 2007, Roth et al. 2007) while marine prey items, such as Little Auk and Black Guillemots (Cepphus grylle), have $\delta^{13} \mathrm{C}$ values ranging from -18 to $-20 \%$ (Figure 5, Hobson et al. 2002). Other prey species taken in more limited quantities, such as shorebirds (e.g., Red Knot [Calidris canutus] and Ruddy Turnstone [Arenaria interpres]) and waterfowl (e.g., Long-tailed Duck [Clangula hyemalis]) have $\delta^{13} \mathrm{C}$ values with much wider ranges $(-16.6$ to $-24.7 \%$ o, -18.1 to $-24.1 \%$, $\sim-17$ to $-21 \%$, respectively), mainly as a result of seasonal shifts in foraging between marine and terrestrial areas (Morrison and Hobson 2004, Braune et al. 2005).

In Kangerlussuaq, $\delta^{13} \mathrm{C}$ values for each of the oldest ${ }^{14} \mathrm{C}$ dated nests ranged from -23.2 to $17.8 \%$. Nest 082 has the most negative $\delta^{13} \mathrm{C}$ value and is closest to the current ice sheet ( 5 $\mathrm{km})$, and nest 201A has the least negative $\delta^{13} \mathrm{C}$ value and is farthest from the ice sheet $(78 \mathrm{~km}$, Figure 5). Of particular interest is nest 087A, which is the oldest sampled nest in Kangerlussuaq by $\sim 1000$ years, and has the median $\delta^{13} \mathrm{C}$ of the nine nests sampled in Kangerlussuaq. While this nest is $54 \mathrm{~km}$ from the current ice sheet, it is approximately $1 \mathrm{~km}$ from a large fjord, allowing adult Gyrfalcons potential access to both a marine and terrestrial diet. The benefit of readily accessing such a large variety of prey may have allowed for earlier colonization of the nest-site. For Thule, nests $500 \mathrm{~A}$ and 501 have very negative $\delta^{13} \mathrm{C}$ values, with nest $500 \mathrm{~A}$ almost $100 \mathrm{~km}$ from the nearest breeding seabird colonies and prey remains consisting almost solely of Arctic Hare in recent years, and nest 501 in a large wetland area, with prey remains primarily consisting of Rock Ptarmigan. The other two Thule nest sites, 502 and 503A, are in areas with large numbers of Little Auks and Black Guillemots. For both study areas, multiple samples from the same nest site show changes of up to $-3 \%$ o in $\delta^{13} \mathrm{C}$ over time (e.g., site 087 in Kangerlussuaq, Table 1), which is likely the result of changes in prey composition over time.

On the basis of palaeoenvironmental investigations by others, we hypothesized that Gyrfalcon nest sites of higher elevations, and further from the ice margin, would show longer usage patterns than nest sites closer to the ice edge, and at lower elevations. Both predictions were confirmed using ${ }^{14} \mathrm{C}$ dating. Carbon dating of stratified guano accumulation at Gyrfalcon nest-sites could thus be used to 
confirm and date when local environments were suitable for breeding by this species and when colonization probably occurred. Furthermore, past use of sites indicates that favorable environmental conditions existed for prey species as well. Values from $\delta^{13} \mathrm{C}$ provide insight into likely prey species that existed at the time of colonization and possible changes in prey species over time. While results from this study are specific to Kangerlussuaq and Thule, it is somewhat likely that similar correlations exist in other regions of Greenland. These results shed further light on local, and probably regional, palaeoenvironmental conditions and glaciation in the Arctic.

\section{ACKNOWLEDGMENTS}

First and foremost we thank Andrew Gosler, Jennifer Burnham, Jeff Johnson, Chris Perrins, and David Houston for comments and suggestions. Additionally, Konrad Steffen, University of Colorado, USA, provided helpful remarks on this manuscript and suggested citations related to glaciation and paleoenvironments in Greenland. Edward Hanna, University of Plymouth, United Kingdom, provided further citations related to glaciation and paleoenvironments in Greenland. Thank you to the Greenland Home Rule Government and Danish Polar Center for providing permits for this research. Additionally, the support of KISS, VECO, $109^{\text {th }}$ Air National Guard, and the United States Air Force were critical in supporting field work. Brian and Ruth Mutch, Jack Cafferty, Jack Stephens, Robin Abbott, Earl Vaughn, Ed Stockard, and the residents of both Kangerlussuaq and Thule Air Base deserve special thanks for their continued friendship and assistance. Financial support was provided by The Peregrine Fund, Ruth O. Mutch, The Offield Family Foundation, Peter Pfendler, Comer Science and Education Foundation, and The G. Unger Vetlesen Foundation and is greatly appreciated.

\section{Literature Cited}

Angerbjörn, A., P. Hersteinsson, K. Lidén, AND E. Nelson. 1994. Dietary variation in Arctic Foxes (Alopex lagopus) - An analysis of stable carbon isotopes. Oecologia 99:226-232.

Beta Analytic, Inc. 2005. 4985 S. W. Court, Miami, FL, 33155, USA.

Www.radiocarbon.com.

Booms, T., AND M. Fuller. 2003. Gyrfalcon diet in central west Greenland during the nesting period. Condor 105:528-537.

BOWDLER, S. 1984. Hunter Hill, Hunter Island: archeological investigation of a prehistoric Tasmanian site. Terra Australis 8. Australian National University Press, Canberra, Australia.

Braune, B. M., K. A. Hobson, and B. J. MaLONE. 2005. Regional differences in collagen stable isotope and tissue trace element profiles in populations of Long-tailed Duck breeding in the Canadian Arctic. Science of the Total Environment 346:156-168.

BURNHAM, K. K. 2008. Inter- and intraspecific variation of breeding biology, movements, and genotype in Peregrine Falcon Falco peregrinus and Gyrfalcon F. rusticolus populations in Greenland. D. Phil. thesis, University of Oxford, Oxford, UK.

Burnham, W. A., AND W. G. Mattox. 1984. Biology of the Peregrine and Gyrfalcon in Greenland. Meddelelser om Grønland: Bioscience 14:1-25.

CADE, T. J. 1960. Ecology of the Peregrine and Gyrfalcon populations in Alaska. University of California Publications in Zoölogy 63:151-290.

CADE, T. J. 1982. The Falcons of the World. William Collins Sons and Co Ltd., London, UK.

Davies, W. E., D. B. Krinsley, And A. H. NiCOL. 1963. Geology of North Star Bay area, northwest Greenland. Meddelelser om Grønland 162:1-68.

Dowdeswell, J. A. 1996. Glaciers in the High Arctic and recent environmental change. Pages 121-134 in P. Wadhams, J. A. 
Dowdeswell, and A. N. Schofield (Eds.). The Arctic and Environmental Change. Gordon and Breach Publishers, London, UK.

EISNER, W. R., T. E. Tornqvist, E. A. Koster, O. BENNIKE, AND J. F. N. VAN LEEUWEN. 1995. Paleoecological studies of a Holocene lacustrine record from the Kangerlussuaq (Søndre Strømfjord) region of West Greenland. Quaternary Research 43:55-66.

EMSlie, S. D., L. CoATS, ANd K. Licht. 2007. A 45,000 yr old record of Adélie Penguins and climate change in the Ross Sea, Antarctica. Geology 35:61-64.

FREDSKILD, B. 1973. Studies in the vegetational history of Greenland. Meddelelser om Grønland 198:1-245.

FREDSKILD, B. 1985. The Holocene vegetational development of Tugtuligssuaq and Qeqertat, northwest Greenland. Meddelelser om Grønland, Geoscience 14:120.

FristruP, B. 1966. The Greenland Ice Cap. Rhodos, International Science Publishers, Copenhagen, Denmark.

FUNDER, S. 1989. Quaternary geology of the ice-free areas and adjacent shelves of Greenland. Pages 741-792 in R. J. Fulton (Ed.). Quaternary Geology of Canada and Greenland, Geological Survey of Canada, Ottawa, Canada.

Gaston, A. J., AND G. Donaldson. 1995. Peat deposits and Thick-billed Murre colonies in Hudson Strait and Northern Hudson Bay: Clue to post-glacial colonization of the area by seabirds. Arctic 48:354-358.

HiCKEY, J. J. 1942. Eastern population of the Duck Hawk. Auk 59:176-204.

Hiller, A., U. WAND, H. KäMPF, AND W. STACKEBRANDT. 1988. Occupation of the Antarctic continent by petrels during the past 35,000 years: Inferences from a ${ }^{14} \mathrm{C}$ study of stomach oil deposits. Polar Biology 9:69-77.

Hobson, K. A., G. Gilchrist, and K. FalK. 2002. Isotopic investigations of seabirds of the north water polynya: Contrasting trophic relationships between the eastern and western sectors. Condor 104:1-11.

Johnsen, S. J., W. DansgaArd, H. B. Clausen, and C. C. Langway. 1970. Climatic oscillations 1200-2000 AD. Nature 227:482-483.

Kelly, M., S. Funder, M. Houmark-NiElsen, K. L. KnUdSen, C. Kronborg, J. LandViK, AND L. SORBY. 1999. Quaternary glacial and marine environmental history of northwest Greenland: A review and reappraisal. Quaternary Science Reviews 18:373-392.

Malaurie, J., Y. Vasari, H. Hyvarinen, G. DELIBRIAS, AND J. LABEYRIE. 1972. Preliminary remarks on Holocene paleoclimates in the regions of Thule and Inglefield Land, above all since the beginning of our own era. Pages 10-133 in Y. Vasari, H. Hyvarinen, and S. Hicks (Eds.). Climatic Changes in Arctic Areas during the last Ten-thousand Years: A Symposium Held at Oulanka and Kevo, 4-10 October 1971. Acta Universitatis Ouluensis, Series A, Scientiae Rerum Naturalium No. 3, Geologica No. 1, University of Oulu, Oulu, Finland.

McGhee, R. 1972. Climatic change and the development of Canadian Arctic cultural traditions. Pages 39-57 in Y. Vasari, H. Hyvarinen, and S. Hicks (Eds.). Climatic Changes in Arctic Areas during the last Ten-thousand Years: A Symposium Held at Oulanka and Kevo, 4-10 October 1971. Acta Universitatis Ouluensis, Series A, Scientiae Rerum Naturalium No. 3, Geologica No. 1, University of Oulu, Oulu, Finland. Morrison, R. I. G., AND K. A. Hobson. 2004. Use of body stores in shorebirds after arrival on High-Arctic breeding grounds. Auk 121:333-334.

NewTon, I. 1979. Population Ecology of Raptors. T. \& A. D. Poyser, Berkhamsted, UK.

OAKLEAF, R. 2003. Peregrine restoration from a state biologist's perspective. Pages 297304 in T. J. Cade and W. Burnham (Eds.). Return of the Peregrine: a North American saga of tenacity and teamwork. The Peregrine Fund, Boise, Idaho, USA. 
Ohmura, A., P. Calanca, M. Wild, And M. ANKLIN. 1999. Precipitation, accumulation and mass balance of the Greenland Ice Sheet. Zeitschrift für Gletsherkunde und Glazialgeologie 35:1-20.

RatClifFe, D. 1993. The Peregrine Falcon. T. \& A. D. Poyser, London, UK.

REEH, N. 1984. Reconstruction of the glacial ice covers of Greenland and the Canadian Arctic islands by three-dimensional, perfectly plastic ice-sheet modeling. Annals of Glaciology 5:115-121.

Ricca, M. A., A. K. Miles, R. G. Anthony, X. Deng, AND S. S. O. Hung. 2007. Effect of lipid extraction on analyses of stable carbon and stable nitrogen isotopes in coastal organisms of the Aleutian archipelago. Canadian Journal of Zoology 85:40-48.

Roth, J. D., J. D. Marshall, D. L. Murray, D. M. NiCKERSON, AND T. D. STEURY. 2007. Geographical gradients in diet affect population dynamics of Canada Lynx. Ecology 88:2736-2743.
ROUNICK, J. S., AND M. J. WINTERBOURN. 1986. Stable carbon isotopes and carbon flow in ecosystems. BioScience 36:171-177.

Salomonsen, F. 1950. Grønlands Fugle. The Birds of Greenland. Munksgaard, Copenhagen, Denmark.

Stuiver, M., P. J. Reimer, E. BArd, J. W. Beck, G. S. Burr, K. A. Hughen, B. Kromer, G. MCCORMAC, J. VAN DER Plicht, AND M. SPuRK. 1998. IntCal98 radiocarbon age calibration, 24,000-0 cal BP. Radiocarbon 40:1041-1083.

Talma, A. S., ANd J. C. Vogel. 1993. A simplified approach to calibrating C14 Dates. Radiocarbon 35:317-322.

Ten Brink, N. W., AND A. WeIdick. 1974. Greenland Ice Sheet history since the last glaciation. Quaternary Research 4:429440 . 